\title{
Comparison and Evaluation of Bank Efficiency in Austria and the Czech Republic
}

\section{- Svitálková Zuzana}

\begin{abstract}
This article compares and evaluates the efficiency of the banking sector in Austria and the Czech Republic in the period 2004-2011. The paper is divided into the following parts. It begins with a literature review dealing with the bank efficiency generally and then with the efficiency of the banking sector in chosen countries. The second section provides an overview of used methodology. The non-parametric Data Envelopment Analysis (DEA) with undesirable output is used for estimating the efficiency. The undesirable output is usually omitted by current authors. Simultaneously were used CCR and BCC models that differ in returns to scale. Section three summarizes the results, discusses them and compares the estimated efficiency rates in both states. This study also attempts to further identify the main sources of inefficiency.
\end{abstract}

Keywords: bank efficiency, inefficiency indicator, DE $A$ with undesirable output

JEL Classification: G21

\section{INTRODUCTION}

Each country should try to build the most advanced banking system because the better bank system the state has the more competitive the state is - according to the study Berger, Hassan, Klapper 2004 (An International Analysis of Community Banking and Economic Performance). In their study was found an important relationship between the efficiency of bank system and GDP growth (tested in 49 states). This result confirms also the paper from Wachtel (2003), Kohler and Cecchetti (2009). According them the well-functioning banking system enables better allocation of resources and investments. In current strong competitive financial environment is necessary to work as efficient as possible and do not have unnecessary extra costs. The aim of this paper is to measure the economic efficiency in Austria and Czech Republic in the period 2004 - 2011 and to compare and discuss the results and to find the most important sources of inefficiency.

According to the term 'efficiency' could be understood technical efficiency - producing maximum output from a given set of inputs (to have a good combination of inputs and outputs). The other type of efficiency is allocative efficiency, where optimal inputs and outputs are chosen based on price in the market. Economic efficiency is than a connection both above mentioned terms. It is the ability to choose the inputs and outputs to optimize the economic goal, usually to maximize profits and to minimize costs.

Measuring the level of economic efficiency of the banking system can help to identify the performance of measured units and if there is some way for the eventual improvement. These measurements may provide valuable information for bank managers for their decision making. Inefficient banks have, in accordance to the article from Fioderlisi, Marques-Ibanez and Molyneux (2010), Williams (2004) and Altunbas et al. (2007) the tendency to make risky steps, which are 
dangerous for the entire financial system. Furthermore, the authors found, that banks, reaching the high productivity, operate with lower costs and do not tend to do operations that include moral hazard (raising amount of short term funds for financing long term activities). Banks with balanced capital structure (finance short term activities with short term funds and long term with long term funds and have sufficient capital adequacy ratio) can afford to make business with higher risk.

For estimating the efficiency exist standard performance indicators, for example ROA (Return of asset), ROE (Return of equity), ROI (Return of investment) and other finance analysis indicators. All these indicators have a big disadvantage. To evaluate the bank efficiency it is necessary to compare a lot of results and to know the recommended range where the results are good or bad.

The main authors in the literature review deal with the estimation of bank systems in one country. Only some authors compared efficiency of bank systems in more states. More recent studies concentrate on Asia countries and emerging markets, Barros, Managi, Matousek 2011; Yung-Ho Chiu, Chin-Wei Huang, Chung-Te Ting 2011; Fukuyama, Weber 2009. Only rare authors analysed the bank efficiency in CEE countries. Only few authors analysed the efficiency of Czech banking sector (Stavárek, Řepková 2011; Stavárek, Polouček 2004; Staněk 2010; Matoušek, Taci 2005; Taci, Zampieri 1998). All these works used the parametric or nonparametric techniques without including risk (undesirable outputs). In this article the undesirable output as the risk factor will be included. Indeed, all the former studies investigating bank efficiency in transition countries aim at estimating bank performance for transition countries, without any comparison to Western European countries. Staněk 2010 estimated the efficiency in Czech Republic and Austria, but he used the Stochastic Frontier Analysis. No authors to my knowledge has yet compared the efficiency in CEE countries and in Austria, however all these countries are very close connected because of a lot of Austrian branches (7) and subsidiaries (6) in these countries.

\section{METHODOLOGY AND DATA}

Recently there are two basic methods of efficiency estimation - parametric (econometric) and nonparametric (mathematical programming). In both cases is the measured efficiency compared with the 'best practice frontier' in the group of investigated DMUs (Decision making units, in this study is one DMU one bank).

The most frequently used parametric method is SFA (Stochastic Frontier Analysis). This method has a big disadvantage the model must be exactly defined. The DEA (Data Envelopment Analysis) is a nonparametric method which allows quantification of the efficiency in one number and is formed as a piecewise linear combination of best-practice observations. Nonparametric approach is more suitable for bank efficiency ranking (Kamecka 2010, Apergis 2011, Holod a Lewis 2011, Ševčovič, Halická, Brunovský 2001).

Advantage of the DEA model is the identification of sources and level of inefficiency for inefficient DMUs (Stavárek, Řepková 2011). One more advantage is that the technique works without the need for standardisation. 
Classical DEA models, described in Charnes, Cooper, Rhodes (1978) rely on assumption that inputs have to be minimized and outputs maximized (or conversely minimisation of outputs and maximization of inputs in the models oriented of inputs). A lot of authors applied this methodology in their articles. Casu, Molyneux (2000) investigated the bank efficiency in EU after joining in the EU. Fioderlisy, Marques (2010) examined the bank risk and efficiency. Ševčovič, Halická, Brunovský (2001) investigated the level of performance of bank branches in Slovakia, Stavárek, Repková (2011) estimated the efficiency of Czech banking industry. All these papers used the simply DEA CCR (constant returns to scale) and BCR (variable returns to scale) model. The simple models ignore the undesirable outputs. But it is necessary to decrease these 'bad outputs' and increase the desirable outputs to improve the performance of DMU. As an undesirable output is in bank accounting considered 'loan loss provision'. It is a non-cash expense for banks to account for estimated potential losses on loan defaults in loan portfolio and also single deals.

In his paper is used output-oriented model which maximizes output levels without increasing inputs. Banks usually cannot set their inputs independently and rather respecting the given market price (salaries, deposit interest rates etc.), Kamecka 2010.

In the model are $n$ DMUs (banks) which are evaluated, indexed by $j=1, \ldots, n$

The input and output vectors of $\mathrm{DMU}_{\mathrm{j}}$ is $\mathrm{X}_{\mathrm{j}}=\left(\mathrm{x}_{1 \mathrm{j}}, \ldots, \mathrm{x}_{\mathrm{ij}}\right)$ and $\mathrm{Y}_{\mathrm{j}}=\left(\mathrm{y}_{1 \mathrm{i}}, \ldots, \mathrm{y}_{\mathrm{ij}}\right)$

In this article is used the indirect approach, it means the transformation of undesirable outputs (we set as variable di the constant for recalculating the undesirable outputs to plus sign values: $\left.\mathrm{d}_{\mathrm{i}}=\max _{\mathrm{j}}\left(\mathrm{y}_{\mathrm{ij}}\right)+1\right)$.

$\psi_{i j}=-y_{i j}+d_{i}, i \in U O$

$\psi_{\mathrm{ij}} \ldots$...transformed undesirable outputs; UO....undesirable outputs, DO...desirable outputs, I... inputs

The undesirable outputs are positive now, we can consider them as normal outputs and it is possible to maximize them.

$$
\begin{aligned}
& \mathrm{T}=\left\{(X, Y) \mid X \geq \sum_{j=1}^{n} \lambda_{j} X_{j}, Y \leq \sum_{j=1}^{n} \lambda_{j} Y_{j}, \lambda_{j} \geq 0, j=1, \ldots, n\right\} \\
& \operatorname{Max} g=\theta_{q}-\varepsilon\left(\sum_{i \in I} s_{i}^{-}+\sum_{i \in D O} s_{i}^{+}+\sum_{i \in U O} s_{i}^{+}\right)
\end{aligned}
$$

$\lambda=$ intensity variables that form linear combinations of observed inputs and outputs with variable return to scale imposed by the constant: $\sum_{j} \lambda_{j}=1$;

$\theta_{q} \ldots$ degree of efficiency of virtual unit (the system looks for the combination of virtual inputs and outputs which are better or worse than the inputs and outputs of estimated Unit); $s_{i}^{+}, \mathrm{s}_{i}$ ...slacks (distance from production possibility frontier); $\varepsilon$... infinitesimal constant which ensures inclusion of all inputs and outputs to the model at least in this value, it is usually $10^{-8}$

The DMU is efficient if $(x, y) \in T$. In this situation no less or any more input can produce the same output or if the same input can produce no more any single outputs. (Fukuyama, Weber 2009) 


\section{Constrain:}

$\sum_{j=1}^{n} \lambda_{j} x_{i j}+s_{i}^{-}=x_{i q}, i \in I$

$\sum_{j=1}^{n} \lambda_{j} y_{i j}-s_{i}^{+}=\theta_{q} y_{i q}, i \in D O$

$\sum_{j=1}^{n} \lambda_{j} \psi_{i j}-s_{i}^{+}=\phi_{q} \psi_{i q}, i \in U O$

$\lambda_{j} \geq 0, s_{i}^{+} \geq 0, s_{i}^{-} \geq 0$

$V R S: \sum_{j=1}^{n} \lambda_{j}=1$

CRS : $\sum_{j=1}^{n} \lambda_{j}-$ free

Efficient units have the efficiency $=1$. The units with higher level of measured efficiency are not effective and have to improve the inputs, desirable outputs and undesirable outputs in this way:

$x_{i j}^{\prime}=x_{i j}-s_{i}^{*+}, i \in I$;

$y_{i q}^{\prime}=\Phi_{q}^{*} y_{i q}+s_{i}^{*+}, i \in D O$

$y_{i q}^{\prime}=d_{i}-\left(\Phi_{q}^{*} \Psi_{i q}+s_{i}^{*+}\right), i \in U O$

All symbols with * are the vectors of optimal values of the models.

The dataset for both states was obtained from Bankscope - Bureau van Dijk database. From both states were selected 9 - 12 biggest banks according to the amount of total assets. Estimated dataset comprises approximately $75-80 \%$ of the whole market.

The paper focuses only on commercial banks. Other specialized banks (central banks, investment banks, securities houses, etc.) were not included in this study. As inputs were selected: personnel costs, deposits, fixed assets and as outputs net interest revenue, loans and as an undesirable output loan loss provision. This selection is consistent with the intermediary approach. It is the traditional role of the bank which collects the deposits and funds from the clients that have a money surplus and distributes these funds to them which have a lack of money for their investment and other needs. Of course the bank makes a profit of these deals. The same approach and variables used also Apergis (2011), Holod, Lewis (2011), Andrie, Cocris (2010), Stavárek (2004).

All data were used from unconsolidated financial statements, annual periodicity. All data were adjusted for inflation $(2005=100 \%)$. For conversion of results in Czech crowns were used the exchange rate from 31.12.20XX. Selected period was 2004 - 2011. In the year 2004 the Bank for International Settlements introduced the regulation Basel II. All financial institution had to gradually adjust its financial statements, information and accounting systems and methodology according this rule. Basel II went into effect in 2008. Both states cooperate economically very close. The Austrian income from their investment in Czech Republic are in the year 2011: 1.363 mil.€ (all incomes from all EU states are 7.705 mi.€). (Source: Einkommen aus österreichischen Direktinvestitionen im Ausland nach Regionen. Österreichische Nationalbank) 
Austrian banks started to expand after the political changes in 1989 to Czech Republic and opened here new branches and subsidiaries. The main connection with these bank systems is through Erste Group, Raiffeisen Bank and Bank Austria. These banks have approximately 35\% share of the total assets of the Czech banking sector. (Source: Banky a pobočky zahraničních bank. Česká národní banka). Both sates have a universal bank system and accounting reported in international accounting standard (my estimated banks had all the financial statements according to IFRS Standard). For the estimation was used the dataset form Bankscope Database. The balance sheet date was in all chosen banks 31.12.20XX. Below are mentioned some bank system characteristics and macroeconomic indicator.

Tab. 1 - Bank sector indicators. Source: International Monetary Fund.

\begin{tabular}{|l|c|c|c|c|c|c|c|c|}
\hline \multirow{2}{*}{} & \multicolumn{5}{|c|}{ Austria } & \multicolumn{4}{c|}{ Czech Republic } \\
\cline { 2 - 9 } & 2008 & 2009 & 2010 & 2011 & 2008 & 2009 & 2010 & 2011 \\
\hline $\begin{array}{l}\text { Regulatory Tier 1 Capital } \\
\text { to Risk-Weighted Assets }\end{array}$ & 9.3 & 11.1 & 11.8 & 47.7 & 11.2 & 12.2 & 13.6 & 14.1 \\
\hline $\begin{array}{l}\text { Non-performing Loans } \\
\text { Net of Provisions to } \\
\text { Capital }\end{array}$ & 8.6 & 6.3 & 6.1 & 30.3 & 11.6 & 18.8 & 25.2 & 25.0 \\
\hline $\begin{array}{l}\text { Non-performing Loans } \\
\text { to Total Gross Loans }\end{array}$ & 1.9 & 2.3 & 2.5 & 10.8 & 2.5 & 4.0 & 5.3 & 5.5 \\
\hline Return on Assets & 0.1 & 0.1 & 0.3 & 0.6 & 1.3 & 1.3 & 1.4 & 1.3 \\
\hline Return on Equity & 2.6 & 1.5 & 4.9 & 9.5 & 24.4 & 23.8 & 22.2 & 20.2 \\
\hline $\begin{array}{l}\text { Interest Margin to Gross } \\
\text { Income }\end{array}$ & 64.6 & 69.7 & 66.5 & 249.2 & 62.5 & 60.3 & 61.9 & 63.8 \\
\hline $\begin{array}{l}\text { Non-interest Expenses } \\
\text { to Gross Income }\end{array}$ & 90.4 & 86.0 & 81.5 & 335.1 & 49.0 & 43.4 & 44.6 & 46.3 \\
\hline $\begin{array}{l}\text { Liquid Assets to Total } \\
\text { Assets (Liquid Asset } \\
\text { Ratio) }\end{array}$ & 26.8 & 26.1 & 24.6 & 102.7 & 26.4 & 28.5 & 30.3 & 30.8 \\
\hline $\begin{array}{l}\text { Liquid Assets to Short } \\
\text { Term Liabilities }\end{array}$ & 69.7 & 76.2 & 72.3 & 292.3 & 73.7 & 75.6 & 74.6 & 74.7 \\
\hline $\begin{array}{l}\text { Net Open Position in } \\
\text { Foreign Exchange to } \\
\text { Capital }\end{array}$ & 1.6 & 0.6 & 0.5 & 0.9 & 2.4 & 0.4 & 0.3 & -0.1 \\
\hline
\end{tabular}

As mentioned in Tab. 1, in both states banks have a good capital adequacy and the Tier 1 capital to risk weighted assets is higher than recommended ratio $8 \%$. Non-performing loans are higher in Czech Republic, that's why we could suppose lower efficiency of Czech Banking System. In the other way, Czech Republic achieved better return on assets and equity because of higher margins and not so saturated market. Interest margin is very similar in both states, except the year 2011 in Austria (the ratio was much higher because of low income in this year). Czech Re- 
public has lower non-interest expenses in all years. In estimated countries are the liquidity and interest margins on the approximately same level, Czech Republic is more stable in this indicator. The source of investment is primarily from local deposits. Because of traditionally less risky behaviour of Czech banks have these banks also only a small number of open currency positions which is not very different from Austria. The banks closed most of open FX positions because of fear of impact of financial crisis risk. Despite small differences it can be conclude that Czech Republic and Austria are economically comparable systems.

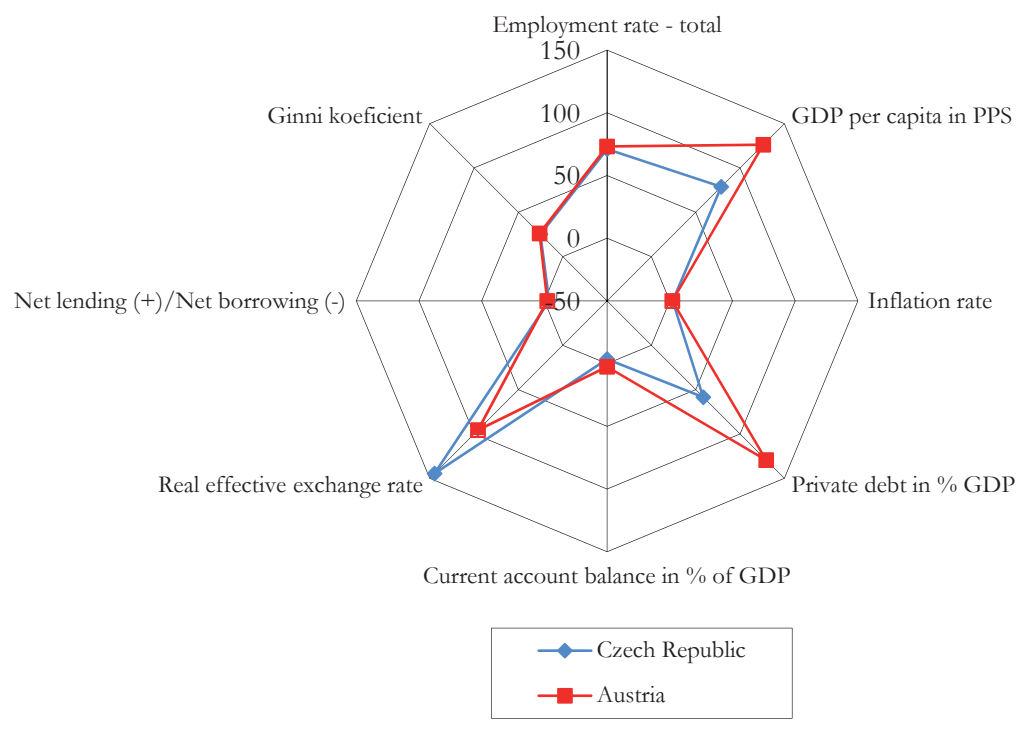

Fig. 1 - Macroeconomic indicators 2008 - 2011. Source: International Monetary Fund.

Fig. 1 shows some macroeconomic indicators in both estimated states. These indicators are the average figures of the years 2008 - 2011. Employment rate is on the same level, GDP per capita in PPS in better in Austria, inflation rate is also nearly identical. Private debt is higher in Austria (as usual in Western countries). Current account balance is about zero in both countries. Real effective exchange rate is higher in Czech Republic. The other two indicators, Ginni coeficient and Net lending/ borrowing are nearly the same. Surprisingly Ginni coeficient in Austria is slightly higher in Austria (progressive income tax rate and other government social politics).

\section{RESULTS AND DISCUSSION}

Comparison between Czech and Austrian bank system in the period 2004 - 2011 is displayed in Tab. 2 and in the Fig. 2. The efficient units have the score $z_{i}^{*}=100 \%$. The further is the distance between achieved efficiency level and 100\% border, the more inefficient the system is. The efficiency of Czech banking sector is in all estimated years and in both models CCR and BCC with undesirable output higher than by Austrian banking sector (except the year 2006 by BCC model). It exist smaller and larger banks on market, which differently influence the whole banking sector 
because of its different market strength. Because of that was used SAE. It recalculates the data set according to the formula:

$$
S A E=\sum_{i=1}^{n} w_{i} z_{i} *
$$

Where $w_{i}$ are weights according to the asset ratio in the estimated file and $z_{i}^{*}$ is the level of efficiency of analysed unit. Also the SAE proves that the Czech banking sector is more efficient. After recalculation according to SAE, all values of efficiency in all years and for both states had deteriorated. These results show that mainly the biggest banks, which have the highest market power, are more inefficient than smaller banks. Bigger banks have very often higher costs for company governance and operation costs. The figure:

$\mathrm{g}^{*}=1 / \mathrm{z}^{*}$

After this conversion have the efficient units value $100 \%$ and inefficient units are in the range $(0,100 \%)$ it is more visible how efficient the unit is.

Tab. 2 - Efficiency level measured by CCR and BCC model with undesirable output. Source: Author's calculation.

\begin{tabular}{|l|l|l|l|l|l|l|l|l|l|}
\hline \multicolumn{2}{|l}{ CCR model } \\
\hline \multicolumn{2}{|l|}{} & 2004 & 2005 & 2006 & 2007 & 2008 & 2009 & 2010 & 2011 \\
\hline \multirow{2}{*}{$z^{*}$} & CZE & $122,75 \%$ & $132,60 \%$ & $135,45 \%$ & $147,71 \%$ & $147,26 \%$ & $143,27 \%$ & $159,09 \%$ & $159,56 \%$ \\
\cline { 2 - 10 } & AUT & $127,73 \%$ & $177,87 \%$ & $177,43 \%$ & $210,14 \%$ & $193,83 \%$ & $223,12 \%$ & $243,31 \%$ & $216,48 \%$ \\
\hline \multirow{2}{*}{ SAE } & CZE & $144,88 \%$ & $144,51 \%$ & $138,90 \%$ & $163,29 \%$ & $167,35 \%$ & $167,05 \%$ & $205,09 \%$ & $202,42 \%$ \\
\cline { 2 - 11 } & AUT & $144,35 \%$ & $201,30 \%$ & $204,63 \%$ & $240,46 \%$ & $209,13 \%$ & $223,42 \%$ & $258,23 \%$ & $238,26 \%$ \\
\hline \multirow{2}{*}{ g* } & CZE & $81,47 \%$ & $75,42 \%$ & $73,83 \%$ & $67,70 \%$ & $67,91 \%$ & $69,80 \%$ & $62,86 \%$ & $62,67 \%$ \\
\cline { 2 - 10 } & AUT & $78,29 \%$ & $56,22 \%$ & $56,36 \%$ & $47,59 \%$ & $51,59 \%$ & $44,82 \%$ & $41,10 \%$ & $46,19 \%$ \\
\hline \multirow{2}{*}{ BCC model } & & & & & & & & \\
\hline \multirow{2}{*}{$z^{*}$} & CZE & $100,37 \%$ & $101,47 \%$ & $101,18 \%$ & $100,38 \%$ & $100,69 \%$ & $101,14 \%$ & $100,78 \%$ & $100,97 \%$ \\
\cline { 2 - 10 } & AUT & $101,39 \%$ & $101,74 \%$ & $100,91 \%$ & $101,49 \%$ & $101,32 \%$ & $101,89 \%$ & $101,73 \%$ & $102,45 \%$ \\
\hline \multirow{2}{*}{ SAE } & CZE & $100,19 \%$ & $100,40 \%$ & $100,30 \%$ & $100,47 \%$ & $100,66 \%$ & $101,65 \%$ & $100,51 \%$ & $100,65 \%$ \\
\cline { 2 - 10 } & AUT & $100,41 \%$ & $100,43 \%$ & $100,22 \%$ & $100,42 \%$ & $100,36 \%$ & $100,40 \%$ & $100,40 \%$ & $100,65 \%$ \\
\hline \multirow{2}{*}{ g* } & CZE & $99,64 \%$ & $98,56 \%$ & $98,84 \%$ & $99,63 \%$ & $99,31 \%$ & $98,87 \%$ & $99,22 \%$ & $99,04 \%$ \\
\hline & AUT & $98,63 \%$ & $98,29 \%$ & $99,10 \%$ & $98,53 \%$ & $98,69 \%$ & $98,15 \%$ & $98,30 \%$ & $97,61 \%$ \\
\hline
\end{tabular}


CCR model z*

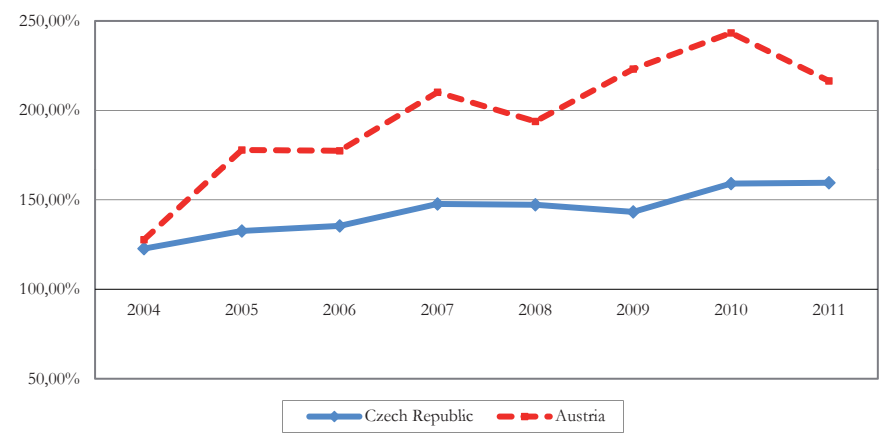

BCCmodel $z^{*}$

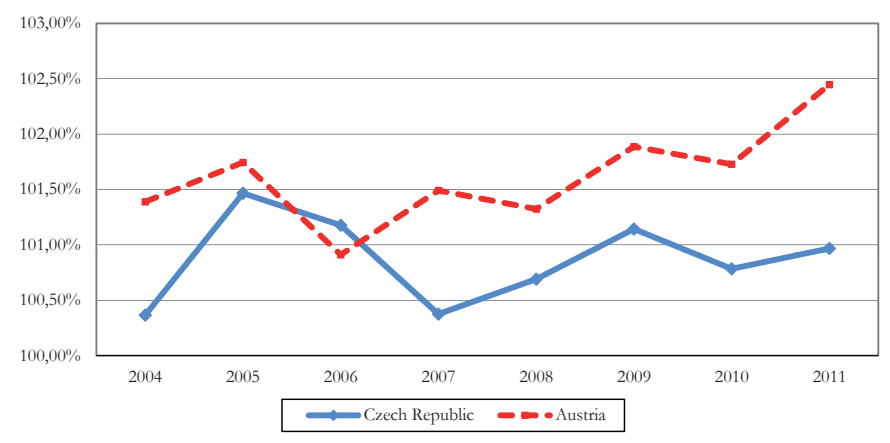

Fig. 2 - Efficiency level measured by CCR and BCC model with undesirable output. Source: Author's calculation.

Fig. 2 shows that banks in 2004 had in both states approximately equal level of efficiency, around $80 \%$ (CCR model, $\mathrm{g}^{*}$ ). Because of historical reasons, Austria has one of the most developed bank system in the EU. The favourable economic situation in Austria in the first half of 2004 was driven primarily by exports, while investment activity and consumer spending rose at a subdued pace. The decision to invest to CEE countries was really a very good step for Austrian banks. Banking markets in CEE benefit from strong demand for banking products and the subsidiaries in CEE generated 40\% (Source: Financial stability report 2004, Osterreichische Nationalbank) of operating incomes of parent companies in Austria in 2004. The increasing energy and oil prices and not sufficient domestic demand decreased the efficiency of Austrian bank system in the next years. Descending exports, increasing oil prices and increasing number of households with an inability to repay their loans caused the deterioration in bank efficiency (number of personal bankruptcy increased from $5.2 \%$ to $16 \%$ ). The number of new loans was going down. The main risks were new loans denominated in foreign currencies $32 \%$ of new loans were in foreign currencies, mainly in Swiss Franc). Favourable economic environment in 2006 caused a reduction of non-performing loans in Austria and had a very positive effect, according to the CRS model with undesirable output. In the course of the year 2007, sustained financial turmoil worldwide led to a downward revision of the economic outlook for both industrialized and CEE countries. These imbalances and also the relatively large share of domestic foreign currency 
loans have contributed to a further increase in both interest rate and exchange rate risks, which have already partly materialized in the next years. Financing via quoted shares almost dried up, and growth in bond-based financing slowed from a high level. Investment is decreasing despite of adverse economic environment. The interest grew further in 2007 and also expenses for new loans because of the higher risk premium. Despite the unfavourable economic situation in 2008 the efficiency of Austrian banks increased. According to CCR model was the growth 4\%. The reason were still increasing loans in the first half of the period and increasing bank profits (banks were able to pass on higher interbank rates arising from tight liquidity conditions). In 2009 , the impact of the crisis on company balance sheets became increasingly visible and external financing also contracted significantly. Furthermore, the conditions and terms for approving loans - interest margins, collateral requirements, the size and maturity of loans granted, the loan covenants as well as the noninterest rate charges were all markedly tightened during this period. The rising risk costs do represent a sizeable burden for the profitability of the Austrian banking system. Overall, the economic recovery and also increase of bank efficiency is visible in 2010 in the model BCC. This growth was primarily export-led with continued sluggish momentum in domestic demand, which had to do with low lending expansion, among other factors. Also the undesirable output, loan loss provision, decreased and that had a positive effect on bank sector efficiency in Austria. In BCC model is visible further decreasing of efficiency in 2011. Austrian banks exhibit very high foreign currency exposure in Austria and in CESEE and the exchange rate risk has materialized in 2011 (the Swiss Franc has appreciated against the Euro and most CESEE currencies have depreciated against the Euro). The structural weaknesses affecting Austrian banks' domestic performance were, however, offset by the continued comparatively favourable performance in CESEE. In the first half of 2011, the operating profits of Austrian banks' subsidiaries, mainly interest income, rose marginally against the same period of the previous year. At the same time, credit risk provisions diminished, so that semi-annual profits were substantially higher than 2010 first-half profits. According to the model CCR the efficiency slacked in 2011, nevertheless the BCC model (variable return to scale) describes more the real situation in the economy. In the study were used both models to confirm the results each other.

The starting position of the $C$ zech banking sector was in the same level of efficiency according to the CCR model with undesirable output and on better level that Austrian according to the BCC model with undesirable output. Czech banks after the process of privatising large banks and clearing their balance sheets of bad debts by transfer and sale to transformation institutions had a good financial condition. The Czech Republic's ratio of total banking sector assets to GDP is at $99.8 \%$, very high by comparison with other new CEE member states of the EU. This is a sign of a relatively developed banking sector, although this ratio for the Czech Republic is also decreasing. Development of ever more sophisticated products, services, sales channels and internal banking processes increased the efficiency in the next years according to the BCC model with undesirable output. The traditional macroeconomic sustainability indicators recorded strongly positive developments in 2007 and also the bank efficiency rose because of that. The public budget deficit fell to $1.6 \%$ of GDP and the ratio of public debt to GDP decreased to $28.7 \%$. The current account deficit declined to $2.5 \%$ of GDP, while the surplus on the output balance increased. Client deposits remain the biggest source of financing for bank loans. At the end of 2007, they were 1.3 times higher than client loans, which, in turn, is more than two times the average in 
the original EU member countries. Deterioration came in 2008 and 2009 when financial crisis affected also Czech Republic. During the financial crisis was the situation in the Czech financial market generally stabilised (visible on the slight increase of inefficiency in CCR model), although low liquidity, weak activity and higher volatility persist in the money market. The deterioration of Czech banking system efficiency since 2009 was caused of recession associated with the collapse of some large debtors, losses from securities holdings in the event of renewed financial market turmoil (e.g. due to restructuring of the sovereign debt of some over-indebted euro area countries), potential liquidity problems in the building society sector and the impact of new regulatory initiatives, mainly indirectly via links to parent companies abroad. Czech banking sector had also during the crisis sufficient capital and remains highly profitable banks. Following quite a robust recovery in 2010, the global economy recorded a modest slowdown in 2011. Weak economic growth and high unemployment are in a vicious circle from which it was difficult to escape. The Czech Republic maintained positive economic growth in 2011, but this growth gradually slowed. Despite the decline in the unemployment rate, the income situation of households deteriorated. Real wage growth was among the lowest in recent history. This unfavourable situation has so far affected the credit risk of households and the impact was visible in an amount of loans provided. Loans are the main product of bank according our model and because of this decrease also decreased efficiency rate of the Czech banking sector in 2011. Czech branches and subsidiaries create the important part of Austrian bank profits on consolidated bases till today.

In Fig. 2, model BCC is visible the one year delay of starting the financial crisis in Czech Republic in 2007 and in Austria in 2006. Between years 2006 and 2007 was the decline $\Delta \mathrm{g}^{*}$ about 10\% in Austria and about $6 \%$ in the Czech Republic, so the financial crisis was apparent. The number of efficient units in Austria is (in both models) smaller than in the Czech Republic and in 2010 and 2011 was in Austria found only one effective unit although in the tested file were more banks from Austria (in Tab.3).

Tab. 3 - Descriptive statistics of measured units. Source: Author's calculation.

\begin{tabular}{|l|l|c|c|c|c|c|c|c|}
\hline \multicolumn{2}{|l}{ CCR model } \\
\hline \multirow{2}{*}{ Year } & State & $\begin{array}{c}\text { Number } \\
\text { of banks }\end{array}$ & $\begin{array}{c}\text { Effec- } \\
\text { tive } \\
\text { units }\end{array}$ & Mean & Median & Std. dev & Min & Max \\
\hline 2004 & CZE & 9 & 4 & 1.227 & 1.050 & 0.275 & 1.000 & 1.642 \\
\cline { 2 - 10 } & AUT & 10 & 4 & 1.277 & 1.371 & 0.247 & 1.000 & 1.558 \\
\hline 2005 & CZE & 11 & 4 & 1.326 & 1.476 & 0.316 & 1.000 & 1.817 \\
\cline { 2 - 10 } & AUT & 10 & 2 & 1.779 & 1.918 & 0.594 & 1.000 & 2.575 \\
\hline \multirow{2}{*}{2006} & CZE & 12 & 3 & 1.354 & 1.242 & 0.392 & 1.000 & 2.273 \\
\cline { 2 - 10 } & AUT & 10 & 1 & 1.774 & 1.825 & 0.538 & 1.000 & 2.628 \\
\hline \multirow{2}{*}{2007} & CZE & 12 & 2 & 1.477 & 1.525 & 0.315 & 1.000 & 1.883 \\
\cline { 2 - 10 } & AUT & 10 & 2 & 2.000 & 2.318 & 0.669 & 1.000 & 2.808 \\
\hline
\end{tabular}




\begin{tabular}{|c|c|c|c|c|c|c|c|c|}
\hline \multirow[t]{2}{*}{2008} & $\mathrm{CZE}$ & 10 & 2 & 1.473 & 1.495 & 0.371 & 1.000 & 2.047 \\
\hline & AUT & 11 & 1 & 1.938 & 2.212 & 0.556 & 1.000 & 2.512 \\
\hline \multirow[t]{2}{*}{2009} & $\mathrm{CZE}$ & 11 & 4 & 1.433 & 1.333 & 0.438 & 1.000 & 2.193 \\
\hline & AUT & 12 & 2 & 2.231 & 2.105 & 1.137 & 1.000 & 4.616 \\
\hline \multirow[t]{2}{*}{2010} & CZE & 11 & 4 & 2.000 & 1.278 & 0.650 & 1.000 & 2.589 \\
\hline & AUT & 12 & 1 & 2.433 & 2.536 & 1.078 & 1.000 & 3.775 \\
\hline \multirow[t]{2}{*}{2011} & $\mathrm{CZE}$ & 10 & 4 & 1.596 & 1.311 & 0.840 & 1.000 & 2.651 \\
\hline & AUT & 12 & 1 & 2.165 & 2.368 & 0.697 & 1.000 & 3.231 \\
\hline \multicolumn{9}{|c|}{ BCC model } \\
\hline \multirow[t]{2}{*}{2004} & $\mathrm{CZE}$ & 9 & 6 & 1.004 & 1.000 & 0.007 & 1.000 & 1.021 \\
\hline & AUT & 10 & 6 & 1.014 & 1.000 & 0.027 & 1.000 & 1.081 \\
\hline \multirow[t]{2}{*}{2005} & CZE & 11 & 8 & 1.015 & 1.000 & 0.026 & 1.000 & 1.067 \\
\hline & AUT & 10 & 6 & 1.017 & 1.000 & 0.025 & 1.000 & 1.060 \\
\hline \multirow[t]{2}{*}{2006} & $\mathrm{CZE}$ & 12 & 7 & 1.012 & 1.000 & 0.015 & 1.000 & 1.035 \\
\hline & AUT & 10 & 7 & 1.009 & 1.000 & 0.015 & 1.000 & 1.038 \\
\hline \multirow[t]{2}{*}{2007} & CZE & 12 & 8 & 1.004 & 1.000 & 0.007 & 1.000 & 1.022 \\
\hline & AUT & 10 & 6 & 1.015 & 1.000 & 0.023 & 1.000 & 1.051 \\
\hline \multirow[t]{2}{*}{2008} & CZE & 10 & 7 & 1.007 & 1.000 & 0.021 & 1.000 & 1.033 \\
\hline & AUT & 11 & 7 & 1.013 & 1.000 & 0.012 & 1.000 & 1.065 \\
\hline \multirow[t]{2}{*}{2009} & CZE & 11 & 7 & 1.011 & 1.000 & 0.020 & 1.000 & 1.060 \\
\hline & AUT & 12 & 7 & 1.019 & 1.000 & 0.036 & 1.000 & 1.124 \\
\hline \multirow[t]{2}{*}{2010} & CZE & 11 & 8 & 1.008 & 1.000 & 0.015 & 1.000 & 1.046 \\
\hline & AUT & 12 & 6 & 1.017 & 1.000 & 0.021 & 1.000 & 1.060 \\
\hline \multirow[t]{2}{*}{2011} & CZE & 10 & 8 & 1.010 & 1.000 & 0.021 & 1.000 & 1.061 \\
\hline & AUT & 12 & 8 & 1.024 & 1.000 & 0.050 & 1.000 & 1.166 \\
\hline
\end{tabular}

In Tab. 3 are the most frequently used descriptive statistic values of relative efficiency. As mentioned the Czech Republic had in both models more efficient bank units than Austria. Czech banks have also smaller standard deviation that Austrian banks so they are more similar and homogenous. This indicates also the 'Max' in the table. In Czech banking sector are the 'Max values' not so high that in Austrian sector. The software for inefficiency estimation defines also the possible virtual inputs and outputs of all units as if the unit would be on the edge of efficiency. According to the analysis of virtual inputs and outputs were the most significant slacks (gaps between real and virtual input / output) found in the size of fixed assets. Particularly bigger banks hold mostly not always fully utilized buildings and other significant items of tangible assets. In addition, banks have a significant number of branches. The operating costs for running these branches are large. The other sources of inefficiency are personnel costs. In Austria were spent $10 \%$ of the whole personnel costs extra, in the Czech Republic 6\%. High salaries of bank man- 
agement and big broker provisions are the major problems. Nevertheless both these inputs create only small part of bank balance sheet. It is of course the important information for improvement the efficiency and decreasing the costs but the main source on inefficiency were deposits. Their inefficient utilization rate was $18 \%$ in Austria and $11 \%$ in the Czech Republic. The ratio was in Austria bigger because of existence of high number of small and medium regional branches which are above average capitalized but cannot invest as needed. The free liquidity is not fully used and they do not have well developed liquidity risk management. A lot of Austrian banks make in the time of writing the article a huge analysis and some banks (Volksbank) closed nearly a half of their branches in Austria to decrease the costs for operating expenses.

The analysis of virtual outputs detected a big gap between virtual outputs and real outputs. According to the results should both sectors significantly increase their business especially provided loans and achieved interest margin. Together with the increase of loans in connected also increase of loan loss provisions because from a new portfolio of loans would arise sure some new loan loss provisions. The virtual output loan loss provisions should be also increased to get the efficiency frontier. Austria should according to the analysis increase nearly twice more than Czech Republic. Of course in the real situation in the market is not so easy to double the amount of provided loans.

To compare efficiency in the model CCR and BCC with and without undesirable output doesn't reflect the real situation on the market because from every loan portfolio exist some loan loss provisions. To omit the undesirable output would not be the real description on the situation on the market. For this reason was not counted the efficiency according to the two simple CCR and BCC models without undesirable output.

Empirical analysis of other authors analyse the effectiveness in the same countries brought similar results. Stavárek (2004) used the SFA method (profit and cost function) and DEA (CCR simple model) and determines effectiveness in 2003 around 80\%. Stavárek, Řepková in 2011 measured the bank performance of Czech banks around 77\%. He separated Czech banks to three groups: small, medium and large and founds that big banks have the worse efficiency, which was about $20 \%$ lower than small and medium sized banks. Staněk (2010) used the SFA method and investigated the performance of banking sector in Czech Republic and Austria in 20002009, according to him was the efficiency of Czech banks between 67-97\% (the performance was improved during period) and in Austria 91-99\%. According to Staněk is the main reason of the difference between efficiencies of the Czech Republic banking sector and Austrian banking sector the more educated management in Austrian banks in the beginning of the investigated period than in the Czech Republic.

\section{CONCLUSION}

The aim of this paper was to estimate the level of bank efficiency in the Czech Republic and in Austria in the period 2004 - 2011 and to compare them. For the survey were used two models: CCR and BCC with undesirable output. As an undesirable output was chosen 'loan loss provisions'. As inputs were selected personnel costs, deposits and fixed assets, as outputs loans and net interest revenue. In the survey were covered every year 19-24 bank, which account for about 75\% 
of the whole market in estimated states. According to both models the performance of the Czech banking sector was better than Austrian banking sector. In the Czech Republic were also more efficient units compared to Austria during the estimated period. The efficiency of both banking sectors was nearly on the same level according to the CCR model in 2004 and in accordance with this model with constant return to scale decreased significantly till the year 2007 (in Austria much larger decrease than in Czech Republic). In 2008 came the slight improvement of efficiency in Austria and the rest of estimated years again deterioration in both states. BCC model showed the better position of Czech banking sector in the beginning of period in 2004 but this deteriorated the next year. In Austria, there is visible the earlier entrance of the financial crisis then in the Czech Republic. The efficiency in Austria descended in 2007 and in Czech Republic one year after. Except the slight increase of the level of efficiency in 2010, the performance decreased the rest of the estimated period. The Czech Banking system was not affected as much as Austrian and was more stable. In both states was found the biggest source of inefficiency a huge amount of not well managed free client deposits. The other sources of inefficiency were not fully utilised fixed assets. Banks own a lot of buildings and have a lot of branches, nevertheless a lot of clients still demand the personnel contact on the branch (face to face with account officer) and also the 'virtual banks' begun to build the branch network because of this psychological fact. The next sources were personnel costs which were used in Austria in a more ineffective way than in the Czech Republic. Nevertheless the both models found that banks should much to increase their amount of provided loans (this fact proves also a lot of free deposits). Of course in the real situation in the market is not so easy to double the amount of provided loans. In general Austrian bank system was much more affected of the financial crisis then the Czech banking sector.

\section{References}

1. Altunbas, Y., Carbo, S., Gardener, E. P. M., \& Molyneux, P. (2007). Examining the relationship between capital, risk and efficiency in European banking. European Financial Management, 13(1), 49-70. http://dx.doi.org/10.1111/j.1468-036X.2006.00285.x

2. Apergis, N., \& Alevizopoulou, E. (2011). Bank Efficiency: Evidence from a Panel of European Banks. Panoeconomicus, 58(3), 329-341. http://dx.doi.org/10.2298/PAN1103329A

3. Andrie, A. M., \& Cocris, V. (2010). Comparative Analysis of the Efficiency of Romanian Banks. Romanian Journal of Economic Forecasting, 13(4), 54-75.

4. Banky a pobočky zahraničních bank. (2013, October 6). Česká národní banka. Retrieved November 5, 2013, from https://apl.cnb.cz/apljerrsdad/JERRS.WEB33.SUBJECTS_ COUNTS_DETAIL?p_lang=cz\&p_DATUM=05.06.2014\&p_ses_idx=1

5. Barros, C., Managi, P., \& Matousek, R. (2012). The technical efficiency of the Japanese banks: non-radial directional performance measurement with undesirable output. Omega, 40(1), 1-8. http://dx.doi.org/10.1016/j.omega.2011.02.005

6. Berger, A., Hasan I., \& Klapper, R. (2004). Further Evidence on the Link between Finance and Growth: An International Analysis of Community Banking and Economic Performance. Journal of Financial Services Research, 25(2-3), 169-202. http://dx.doi. org/10.1023/B:FINA.0000020659.33510.b7 
7. Casu, B., \& Molyneux, P. (2000). A Comparative Study of Efficiency in European Banking. Center for Financial Institutions Working Papers 00-17, Wharton School Center for Financial Institutions, University of Pennsylvania. Retrieved January 23, 2013, from http://fic. wharton.upenn.edu/fic/papers/00/0017.pdf

8. Cechetti, S., Kohler, M., \& Upper, Ch. (2009). Financial crises and economic activity. NBER working paper series [online], Nr. 15379. http://dx.doi.org/10.3386/w15379

9. Charnes, A., Cooper, W. W. \& Rhodes, E. (1978). Measuring the efficiency of decisionmaking units. European Journal of Operational Research, 2(6), 429-444. http://dx.doi. org/10.1016/0377-2217(78)90138-8

10. Fiordelisi, F., Marques-Ibanez, D., \& Molyneux, P. (2011). Efficiency and risk in European banking. Journal of banking \& Finance, 35(5), 1315-1326. http://dx.doi.org/10.1016/ j.jbankfin.2010.10.005

11. Fukuyama, H., \& Weber, W.L. (2009). A directional slacks-based measure of technical inefficiency. Socio-Economic Planning Sciences, 43(4), 274-287.

12. Holod, D., \& Lewis, H. (2011). Resolving the deposit dilemma: A new DEA bank efficiency model. Journal of Banking \& Finance, 35(11), 2801-2810. http://dx.doi.org/10.1016/ j.jbankfin.2011.03.007

13. International Monetary Fund. (2013). Data and statistics. [online]. Washington. International Monetary Fund. Retrieved January 15, 2012, from: http://www.imf.org/external/pubs/ft/ weo/2013/02/weodata/weoselser.aspx?c $=122 \& \mathrm{t}=1$

14. Kamecka, M. (2010). EPubWU Institutional Repository. Wirtschaftsuniversität Wien [online], Nr. 1. Retrieved January 23, 2013, from http://epub.wu.ac.at/2028/1/attachment_send.pdf

15. Kohler, M., Cecchetti G.S., \& Upper, Ch. (2009). Financial crisis and economic activity. NBER Working paperseries. Nr. 15379. Retrieved January 23, 2013 from: http://www.nber. org/papers/w15379.pdf

16. Matoušek, R., \& Taci, A. (2005). Efficiency in Banking: Empirical Evidence from the Czech Republic. Economic Change and Restructuring, 37(3), 225-244. http://dx.doi.org/10.1007/ s10644-005-5059-4

17. Osterreichische Nationalbank (2004). Financial stability report [online]. Vienna. Retrieved March 26, 2014, from http://www.oenb.at/en/Publications/Financial-Market/FinancialStability-Report/2004/Financial-Stability-Report-08.html

18. Salas, V., \& Saurina, J. (2003). Deregulation, market power and risk behavior in Spanish banks. European Economic Review, 47(6), 1061-1075. http://dx.doi.org/10.1016/S00142921(02)00230-1

19. Staněk, R. (2010). Efektivnost českého bankovního sektoru v letech 2000-2009. Centrum výzkumu konkurenceschopnosti České republiky [online], Working Paper 09/2010. Retrieved January 15, 2013, from https://is.muni.cz/do/econ/soubory/oddeleni/centrum/papers/ 09Stanek.pdf

20. Stavárek, D. \& Řepková, I. (2011). Efficiency in the Czech banking industry: A nonparametric approach. Acta Universitatis Agriculturale et Silviculturae Mendelleanae Brunensis, 59(2), 299-305. 
21. Stavárek, D. (2004). Efektivnost bank v zemích Visegrádské skupiny. Disertation Thesis. Ostrava: Vysoká škola báňská, Technická univerzita Ostrava.

22. Stavárek, D., \& Polouček, S. (2004). Efficiency and Profitability in the Banking Sector. In Polouček, S. (ed.), Reforming the Financial Sector in Central European Countries, pp. 75-135. Houndmills: Palgrave Macmillan, 75-135.

23. Ševčovič, D., Halická, M., \& Brunovský P. (2001). DEA analysis for a large structured bank branch network. Central European Journal of Operations Research, 9(4), 329-342.

24. Taci, A., \& Zampiery, E. (1998). Efficiency in the Czech Banking Sector. CERGE-EI Discussion Paper 4. Prague: CERGE-EI.

25. Wachtel, P. (2003). How Much Do We Really Know about Growth and Finance?. Economic Review, Federal Reserve Bank of Atlanta, Q1, 33-47.

26. Williams, J. (2004). Determining management behaviour in European banking. Journal of Banking and Finance, 28(10), 2427-2460. http://dx.doi.org/10.1016/j.jbankfin.2003.09.010

27. Yung-Ho, Ch., Chin-Wei, H., \& Chung-Te, T. (2011). Measuring The Repair Performance for Stricken Cultivated Land and Agricultural Efficiency in China with A Modified Two-Stage DEA. Asia-Pacific Journal of Operational Research, 28(5), 633-649. http://dx.doi. org/10.1142/S021759591100348X

\section{Contact information}

Ing. Zurana Svitálková

Mendel University in Brno

Zemédèlská 1, Brno

E-mail: z:svitalkova@gmail.com 